\title{
A new species of Lioptilodes Zimmerman (Lepidoptera, Pterophoridae) from northern Chile
}

\author{
Héctor A. Vargas ${ }^{1}$ \\ 1'Departamento de Recursos Ambientales, Facultad de Ciencias Agronómicas, Universidad de Tarapacá, Casilla 6-D, Arica, Chile. havargas@uta.cl
}

\begin{abstract}
A new species of Lioptilodes Zimmerman (Lepidoptera, Pterophoridae) from northern Chile. Male and female adults of a new species of Lioptilodes Zimmerman (Lepidoptera, Pterophoridae) are described and illustrated. Immature stages are associated with Baccharis scandens (Ruiz \& Pav.) Pers. (Asteraceae). The species was collected in two localities of northern Chile: near sea level in the Azapa valley, in the coastal desert of Arica Province and at $3000 \mathrm{~m}$ elevation in Socoroma, Parinacota Province.
\end{abstract}

KEYWORDS. Asteraceae; Baccharis scandens; Neotropical; taxonomy.

RESUMO. Uma nova espécie de Lioptilodes Zimmerman (Lepidoptera, Pterophoridae) do norte do Chile. Os adultos macho e fêmea de uma nova espécie de Lioptilodes Zimmerman (Lepidoptera, Pterophoridae) são descritos e ilustrados. Os estágios imaturos estão associados com Baccharis scandens (Ruiz \& Pav.) Pers. (Asteraceae). A espécie foi coletada em duas localidades do norte do Chile: vale de Azapa, perto do nível do mar, no deserto litoral da Província de Arica, e aos $3000 \mathrm{~m}$ de altitude em Socoroma, na Província de Parinacota.

PALAVRAS-CHAVE. Asteraceae; Baccharis scandens; Neotropical; taxonomia.

Lioptilodes Zimmerman, 1958 is one of the most diverse genera among Neotropical Pterophoridae and it is also found in the Hawaiian Islands (Gielis 2006). Its phylogenetic relationships remain poorly understood (see Gielis 1993), which is a common characteristic for many groups of Pterophoridae due to the scarce knowledge of this fauna (Matthew \& Landry 2008). However, an outstanding feature in the male genitalia of Lioptilodes is the well developed posterior projection of the saccus, or antisaccus (sensu Gielis 1991).

Twenty-five species of Lioptilodes have been described from many Neotropical countries (Vargas \& Parra 2005; Gielis 2006). Nine species have been recorded from the Chilean territory, mostly from the central and southern areas of the country (Gielis 1991, 2006; Vargas \& Parra 2005). However, no records have been published from northernmost Chile, around the boundary area with Peru and Bolivia. The only pterophorid moth recorded from this zone is Megalorhipida leucodactyla (Fabricius, 1794), which was caught in Azapa, a coastal valley of Arica Province (Vargas 2007), but at least eight other species of pterophorid moths have been identified from Azapa valley (C. Gielis, pers. comm.).

Between October 2008 and July 2009, some specimens of an undescribed species of Lioptilodes were reared from larvae collected on inflorescences of Baccharis scandens (Ruiz \& Pav.) Pers. (Asteraceae) in two localities of northern Chile: the Azapa valley, near sea level, and Socoroma, at $3000 \mathrm{~m}$ elevation, Parinacota Province. The purpose of this work is to describe this new species, based on the adult morphology.

The type material will be deposited in the "Museo Nacional de Historia Natural de Santiago" (MNNC), Santiago, Chile.

\section{Lioptilodes gielisi sp. $\mathbf{n}$.}

(Figs. 1-5)

Type material. Holotype male, CHILE, Parinacota: Socoroma, Parinacota/ Chile/ November 2008/ H.A. Vargas coll.// reared from larva on/ Baccharis scandens/ October 2008 (MNNC). Paratypes, CHILE, Parinacota: one male, three females same data as holotype (MNNC); Chile, Arica: one male, one female Azapa, Arica/ Chile/ February 2009/ H.A. Vargas coll.// reared from larva on/ Baccharis scandens/ January 2009 (MNNC); one male Azapa, Arica/ Chile/ August 2009/ H.A. Vargas coll.// reared from larva on/ Baccharis scandens/ July 2009 (MNNC).

Diagnosis. The species is characterized by the shape of the aedeagus in the male genitalia and the aspect of the sterigma in the female genitalia. The shape of the male genitalia of $L$. gielisi, with the valvae strongly narrowing distally, is shared with three other species in the genus: L. tribonia (Meyrick, 1921), L. limbani Gielis, 1996, and L. cocodrilo Gielis, 2006. However, the short and compressed subdistally aedeagus differentiates $L$. gielisi from its closest relatives, which have the aedeagus strongly curved. In addition, the two trianglelike areas of the lamella postvaginalis are absent in the female genitalia of $L$. tribonia and L. limbani, and a sclerotized, slender longitudinal area is absent in the ductus bursae of $L$. limbani and L. cocodrilo.

Description. Male. Head with compound eyes black; vertex with reddish brown scales projecting forward; frontoclypeus with reddish brown scales and transverse white stripe at ventral margin; occiput reddish brown; antennae filiform, scape white, pedicel reddish brown, flagellomeres with dorsal surface covered with white and reddish brown scales, ventral surface ciliate; labial palpi with first segment white, second and third segments reddish brown. Thorax: dorsal surface 


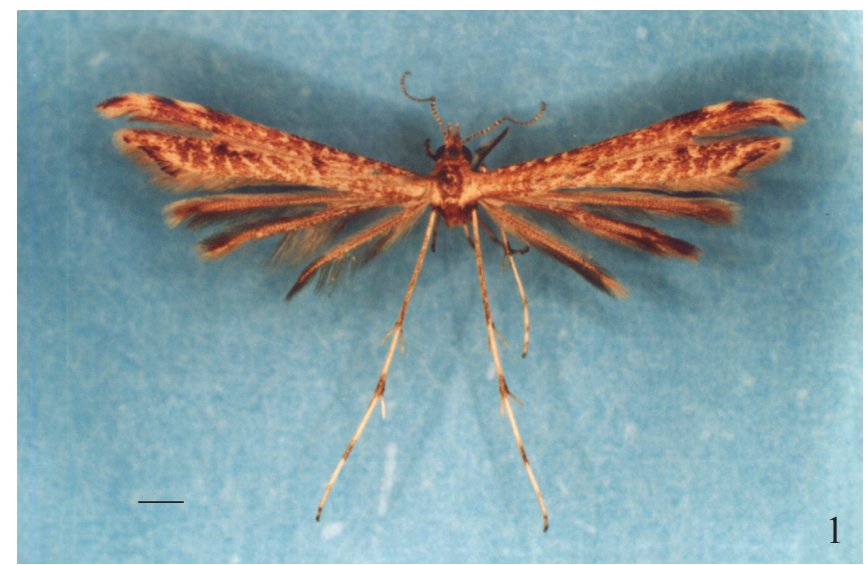

Fig. 1. Lioptilodes gielisi. Holotype male in dorsal view; scale bar $1 \mathrm{~mm}$.

reddish brown; lateral surface of prothorax reddish brown, lateral surface of meso- and metathorax with reddish brown and white scales; prothoracic leg with lateral surface of coxa grey-brown and median surface white, femur and tibia greybrown with some scattered white scales, tibial epiphysis white; meso- and metathoracic legs with femur and tibia with grey-brown and white longitudinal stripes; tarsomeres white at base and grey-brown at apex; one pair of tibial spurs on mesothoracic legs and two pairs on metathoracic legs, grey-brown at base, white at apex; forewing bilobed, reddish brown with many whitish oblique lines, some dark brown scales scattered, costal margin of first lobe with two white spots and three dark brown spots, one dark brown spot at base of second lobe, fringe with reddish brown, dark brown, and white scales; hindwing trilobed, covered with short, smooth and grey-brown scales, fringe grey-brown.

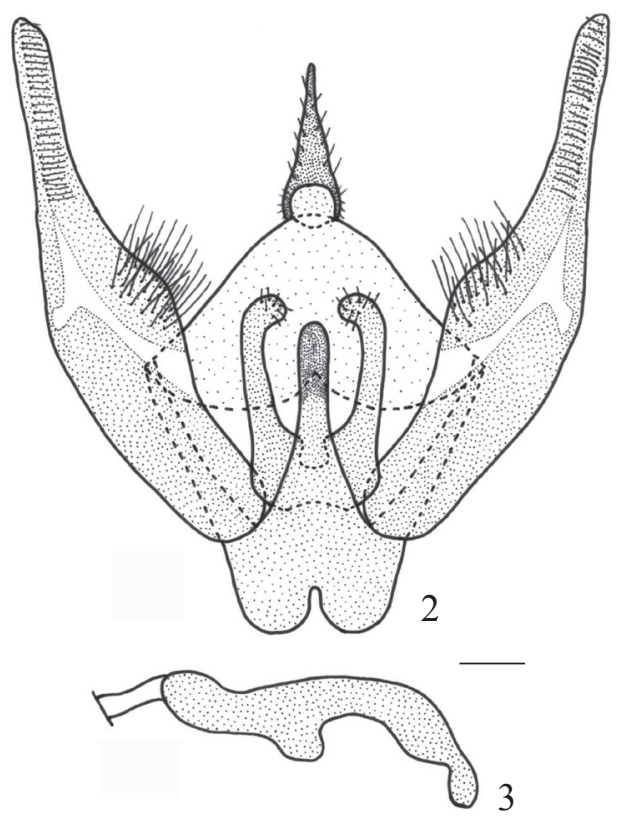

Figs. 2-3. Lioptilodes gielisi. Male genitalia. 2. Male genitalia in ventral view, aedeagus removed. 3 . aedeagus in lateral view; scale bar $0.1 \mathrm{~mm}$.
Abdomen reddish brown with two longitudinal white stripes laterally.

Male genitalia. Uncus simple, pointed, broad at base, gradually narrowing at apex; tegumen with anterior margin broad and excavated, posterior margin narrow; saccus with narrow dorsal arms, anterior margin excavated, posterior projection well developed, nearly reaching apex of juxta; juxta rectangular at base, posterior margin amply excavated, two conspicuous slender posterior projections medially bent at apex; valvae symmetrical, broad at base, narrow distally; aedeagus short, slightly arched, compressed subdistally, coecum slightly developed.

Female. Similar to male, but with sternite VII modified, with posterior margin projected posteriorly, delimiting posterior area slightly more sclerotized than anterior area.

Female genitalia. Sterigma well developed, lamella antevaginalis with anterior margin excavated, laterally continuous with anterolateral area of eighth tergite, lamella postvaginalis in two triangular areas with anterior margin continuous with lamella antevaginalis; ostium bursae medioventrally between triangular sclerotized areas of lamella postvaginalis; antrum not well defined; ductus bursae slender, as long as lamella postvaginalis, membranous, with sclerotized slender longitudinal area; corpus bursae

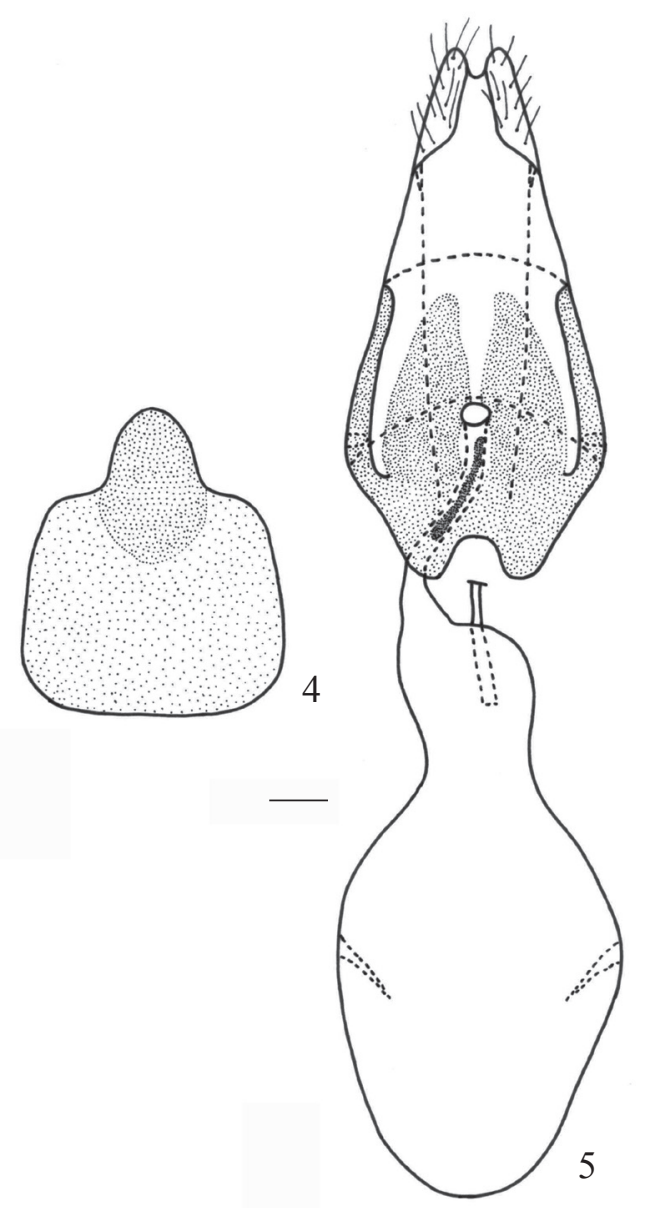

Figs. 4-5. Lioptilodes gielisi. Female sternite VII and female genitalia. 4. Female sternite VII in ventral view. 5. female genitalia in ventral view; scale bar $0.1 \mathrm{~mm}$. 
membranous with two lateral horn-like signa, basal region narrow, distal region broader; ductus seminalis on dorsal surface of basal area of corpus bursae; anterior apophyses short; posterior apophyses long.

Etymology. Lioptilodes gielisi is named in honor of Dr. Cees Gielis, Nationaal Natuurhistorisch Museum, Leiden, The Netherlands, for his outstanding work on world Pterophoridae.

Hostplant. Baccharis scandens (Ruiz \& Pav.) Pers. (Asteraceae).

Remarks. Hostplant records have been previously published only for four other species of Lioptilodes: three in Asteraceae (Vargas \& Parra 2005; Gielis 2006), and one in Fabaceae (Gielis 2006). Thus, the association of L. gielisi with an Asteraceae hostplant fits the pattern recorded for the genus.
Acknowledgements. I thank Marcelo Duarte and an anonymous referee for kind comments and suggestions on a preliminary version of this paper; to Bernard Landry by kindly checking the English version. This study was supported by project DIEXA-UTA 9710-08.

\section{REFERENCES}

Gielis, C. 1991. A taxonomic review of the Pterophoridae (Lepidoptera) from Argentina and Chile. Zoologische Verhandelingen 269: 1-164.

Gielis, C. 1993. Generic revision of the superfamily Pterophoroidea (Lepidoptera). Zoologische Verhandelingen 290: 1-139.

Gielis, C. 2006. Review of the Neotropical species of the family Pterophoridae, part I: Ochyroticinae, Deuterocopinae, Pterophorinae (Platyptiliini, Exelastini, Oxyptilini) (Lepidoptera). Zoologische Mededelingen 80-2: 1-290.

Matthews, D. L. \& B. Landry. 2008. Description of a new species of Exelastis (Lepidoptera: Pterophoridae) from the Neotropics, with keys to adults of the four species occurring in Florida. Tropical Lepidoptera Research 18: $62-69$.

Vargas, H. A. 2007. Megalorhipida leucodactyla (Fabricius) (Lepidoptera: Pterophoridae): first distribution record from Chile and new host plant record. Neotropical Entomology 36: 476-477.

Vargas, H. A. \& L. E. Parra. 2005. Una nueva especie de Lioptilodes Zimmerman (Lepidoptera: Pterophoridae) de Chile. Neotropical Entomology 34: 403-406. 